\title{
Design and technical specifications of steel purse seiners operating along Ratnagiri coast of Maharashtra
}

\section{SIDDHESH DESAI, MAKARAND SHARANGHDHAR AND ASHISH S. MOHITE}

Received : 06.06.2016; Revised : 28.08.2016; Accepted : 13.09 .2016

See end of the Paper for authors' affiliation

Correspondence to :

SIDDHESH DESAI

Department of Fisheries

Engineering, College of

Fisheries, Shirgaon,

RATNAGIRI (M.S.) INDIA

Email : ashishmohite@

yahoo.com
- ABSTRACT : Recently, steel purse seiners were introduced in Ratnagiri, Maharashtra. The present study was an attempt to document the design and technical aspects of steel purse seiners presently operated from Mirkarwada fishing harbour of Ratnagiri. For the steel purse seiners operating along Ratnagiri coast, overall length was recorded to be 19.55 to $19.85 \mathrm{~m}$, breadth at midship $5.79 \mathrm{~m}$ to $6.1 \mathrm{~m}$, depth of vessel $3.1-3.65 \mathrm{~m}$, length of freeboard $1.27 \mathrm{~m}$ to $1.50 \mathrm{~m}$, draught 1.82 to $2.14 \mathrm{~m}$ and length of keel $16.72 \mathrm{~m}$. The steel purse seiners were fitted with engines having maximum horse power of 350 and the minimum horse power recorded was $175 \mathrm{hp}$.

— KEY WORDS : Purse-seining, Steel purse seiners, Design, Technical specifications

- HOW TO CITE THIS PAPER : Desai, Siddhesh, Sharanghdhar, Makarand and Mohite, Ashish S. (2016). Design and technical specifications of steel purse seiners operating along Ratnagiri coast of Maharashtra. Internat. J. Agric. Engg., 9(2) : 184-187, DOI: 10.15740/HAS/IJAE/9.2/184-187. 